\title{
Promoting Access to Primary Equity Markets A Legal and Regulatory Approach
}

\author{
Felice B. Friedman and Claire Grose ${ }^{*}$
}

\begin{abstract}
This paper examines legal and regulatory measures that can be taken to promote access to the primary market in emerging market economies. While capital market development depends on many factors including, primarily, a favorable macroeconomic environment, an appropriately designed and effective legal and regulatory framework can help to encourage market growth and to increase access to finance for all companies, including small-and-medium size enterprises. In this paper we identify the basic necessities that underpin a regulatory regime that is cost effective and strikes an appropriate balance between, on the one hand, laws and regulations that may be too restrictive to achieve a supply of capital and, on the other, those that may be so relaxed that investors feel that there is an unacceptable level of risk and do not care to venture into the market. We explore the legal foundations for the successful operation of a primary market for securities and identify disclosure and effective monitoring and enforcement as essential elements of legal protection. We then examine different legal and regulatory approaches for improving access to finance. We discuss measures that can be used by traditional stock exchanges to attract smaller enterprises to their lists as well as recent initiatives to create second boards or divide the main board into different market segments. We also discuss different mechanisms for companies to raise funds outside of a formal stock market listing, including private placements and private equity. Finally, we propose some recommendations for a simple legal and regulatory framework that will help promote access to primary equity markets, via both the traditional exchange as well as other alternatives.
\end{abstract}

\section{World Bank Policy Research Working Paper 3892, April 2006}

The Policy Research Working Paper Series disseminates the findings of work in progress to encourage the exchange of ideas about development issues. An objective of the series is to get the findings out quickly, even if the presentations are less than fully polished. The papers carry the names of the authors and should be cited accordingly. The findings, interpretations, and conclusions expressed in this paper are entirely those of the authors. They do not necessarily represent the view of the World Bank, its Executive Directors, or the countries they represent. Policy Research Working Papers are available online at http://econ.worldbank.org.

\footnotetext{
* Felice Friedman (ffriedman@worldbank.org) and Claire Grose (cgrose@worldbank.org) are members of the Capital and Risk Markets Group in the World Bank's Financial Sector Vice Presidency. The authors wish to thank Rudi van der Bijl, Alessandra Campanaro, Stijn Claessens, Tadashi Endo, Jorge Familiar, Patrick Honohan, Yongboem Kim, Jeppe Ladekarl, Rodney Lester, Susan Marcus, Tatiana Nenova, Michael Pomerleano and Dimitri Vittas for their valuable comments and suggestions. The authors are especially grateful to Dan Goldblum and Jaehoon Yoo for their contributions to the section on alternative markets.
} 


\section{Introduction}

Strong capital markets are an engine of economic growth. By creating liquidity and generating information, markets encourage people to save and invest, and by increasing savings and investment and allocating risk, they contribute to economic development. ${ }^{1}$ Equity markets can be an effective source of financing for big and small companies alike. Going public may increase a company's status and have a positive impact on its relationships with customers and other outsiders. ${ }^{2}$ In this paper, we look at the question of how to create strong equity markets that can serve as a viable source of financing for domestic companies. We take a legal and regulatory approach to try to answer this question.

Capital market development is a function of a number of different conditions. Primary among these is a favorable macroeconomic environment, but, in addition, there needs to be supportive technical infrastructure, enforceable property rights and a policy that encourages private sector growth, an adequate bankruptcy system that supports creditor rights, well-developed legal and accounting and professions along with accounting and audit standards, and an efficient judicial system accompanied by credible enforcement. Fulfilling all of these conditions is difficult and takes a long time. Nonetheless, progress can be made and is being made. In this paper, we focus in particular on the legal and regulatory conditions necessary for capital market development. Economic growth is facilitated when the market operates under laws, regulation and supervision that cater to its current and future stages of development. Issuers and investors have more confidence in raising and investing funds in the equity market when the legal, regulatory and supervisory framework promotes new issues and, at the same time, provides adequate mechanisms for protecting investors.

Our objective in this paper is to identify the basic necessities that underpin a regulatory regime that is cost effective and strikes an appropriate balance between, on the one hand, laws and regulations that may be too restrictive to achieve a supply of capital and, on the other, those that may be so relaxed that investors feel that there is an unacceptable level of risk and do not care to venture into the market. In attempting to realize this objective we have considered the Objectives and Principles of Securities Regulation adopted by the International Organization of Securities Commissions (IOSCO) and the IOSCO Methodology for assessing their implementation. These high regulatory standards are intended to maintain fair, efficient and transparent markets, protect investors and reduce systemic risk.

Without doubting the importance and universality of the IOSCO Objectives and Principles, we believe that they do not provide a realistic roadmap to capital market development for emerging market economies. Therefore, we are putting forward a list of basic necessities for improving the laws and regulations of many emerging markets. We believe that, for these markets, putting into effect the basic

\footnotetext{
${ }^{1}$ Sylla 1995.

${ }^{2}$ Marchisio and Ravasi 2001
} 
necessities will be a useful step along the way to full implementation of the Principles.

In this paper, we look first at the desirability of promoting access to primary equity markets in small emerging economies. Typically, companies in such markets rely primarily on short-term bank financing, or relatively small capital infusions from family, friends and trading partners. However, while this type of financing is selflimiting and does not promote the broader capital market development necessary to support economic growth, there are many obstacles to creating strong equity markets that can serve as a source of capital for such companies.

We explore the legal foundations for the successful operation of a primary market for securities and identify disclosure and effective monitoring and enforcement as essential elements of legal protection. Then we examine the incentives and impediments that companies face in listing their securities on domestic stock exchanges. We also look at recent initiatives that stock exchanges have taken in an endeavor to attract smaller enterprises to their lists by creating second boards or dividing the main board into different market segments. Stock exchanges, however, are not the only option for equity offers, and in many cases may not be the best available alternative. We therefore discuss different mechanisms for companies to raise funds outside of a formal stock market listing. Finally, we propose some recommendations for a simple legal and regulatory framework that will help promote access to primary equity markets, both the traditional exchange as well as other alternatives.

\section{The Need to Promote Access to Primary Markets}

Much research has been conducted that shows that countries with better developed capital markets, markets that are deep and liquid and that operate smoothly and efficiently, also have stronger overall economies and more rapid economic growth. Equity markets, both formal and informal, are essentially meeting places for investors and sellers. Equity markets mobilize savings, allocate capital and risk, and exert external discipline on issuers. Without equity markets, smaller or riskier businesses may have difficulty finding financing. Without equity markets, banks themselves may have difficulty growing, and providing loans to more people. Without equity markets, investors are likely to be less willing to purchase and hold corporate bonds. ${ }^{3}$ Indeed, "the importance of financial markets in general, and stock markets in particular, for the efficient functioning of an economy cannot be exaggerated." 4 And, as has been well-recognized since the Asian financial crisis of

\footnotetext{
${ }^{3}$ While we focus in this paper on equity markets, corporate debt also can play an important role in expanding capital market development. Typically, the legal and regulatory framework for corporate debt and equity are quite similar. Therefore, much of what we say in this paper about the need to create a fundamental legal and regulatory framework applies equally to the development of a corporate debt market. ${ }^{4}$ Claessens and Revilla, 2005. See, also, F. Lopez-de-Silanes 2005, “A large literature links financial development to economic growth. King and Levine initiate the modern incarnation of this literature by showing that countries with better developed capital markets grow faster in the future.”
} 
the late 1990s, capital markets can serve as an important "spare tire” at times of market stress. ${ }^{5}$

Of course this begs the questions of what constitutes a capital market and how a successful one can be created. Formal organized stock exchanges have been established in many countries in recent years. However, many of these exchanges could not be characterized as successful, either in terms of performance indicators (i.e., liquidity, turnover, new issues, market capitalization, etc.), or in terms of their contribution to domestic economic growth. In many small emerging markets, stock exchanges simply have failed to thrive. They have only a few listings, new public offerings are rare, and there is hardly any trading. While trading frequently also occurs outside of the formal stock exchange on informal over-the-counter markets, these too have failed to generate equity market development on a significant scale.

Globalization and technology, in many ways forces for modernization and development, have contributed to this bleak picture. Where they are able, larger issuers from more advanced emerging markets sometimes escape their domestic constraints and dual list on global markets, particularly the New York Stock Exchange and the London Stock Exchange. For example, "by March 1995, over $87 \%, 54 \%, 62 \%$ and $71 \%$ of the Mexican, Argentine, Chilean and Brazilian local market indices, respectively, were available for trading in the United States in the form of ADRs."6 A recent World Bank study of capital markets in Latin America found, disturbingly, that domestic market reforms resulted in a larger proportion of issuers going abroad, and led to less liquidity and weaker markets at home. ${ }^{7}$

If emerging markets are unable to serve as a major source of capital for their leading issuers, perhaps, in the face of globalization, their strategic focus should be instead on serving the smaller, less well-known domestic issuer. ${ }^{8}$ Indeed, small and medium sized enterprises (SMEs) form the economic backbone of most emerging market economies. Instead of focusing on prime issuers who, it appears, may leave

\footnotetext{
${ }^{5}$ A. Greenspan 2000. "The failure to have alternative forms of intermediation was of little consequence so long as the primary means worked. That is, the lack of a spare tire is of no concern if you do not get a flat. East Asia had no spare tires."

${ }^{6}$ K. Hargis, 2000. "International Cross-Listing and Stock Market Development in Emerging Economies," International Review of Economics and Finance 9, p. 103. In Brazil alone, there has been extensive migration abroad (mainly to the U.S.) since the mid 1990s, particularly of the larger and more prestigious companies.

${ }^{7}$ A. de la Torre, and S. Schmukler, 2004. Of course, even if dual listings detract in theory from the potential liquidity of the domestic market, they can in practice help make a domestic market more liquid than it would be absent the dual listing. By piggybacking on the higher volumes of a large international market, dually listed shares may be able to be traded more efficiently on the domestic market than they would be otherwise. See, e.g., K. Hargis, 2000, who argues that the expansion of cross-listings in Latin America paralleled and contributed to increasing market capitalization. "[I]nternational cross-listings have been instrumental in the development of stock markets in Latin America since 1989, increasing stock prices and issuance of equity and enhancing liquidity.” Id., at p. 103.

${ }^{8}$ Another possible response to the decline in domestic markets is for issuers to turn instead to regional markets. The development and advantages and disadvantages of regional markets is beyond the scope of this paper. Nonetheless, the authors do not believe that regional markets will contribute much to domestic economic growth, at least not for many years.
} 
home as soon as they are able, emerging markets could concentrate on improving access to finance for SMEs, and increasing market participation by domestic retail and institutional investors. However, while many emerging markets support a stock exchange, in most cases this has not seemed to be an effective source of financing for domestic SMEs.

Technological advances, which one would expect to benefit emerging markets and SMEs by lowering the cost of access, have not achieved their anticipated potential. Stock exchanges have not generated listings or finance for SMEs, and government authorities have not found ways to encourage SMEs to turn to public markets for financing. However, for many emerging markets, the growth and financing of SMEs is vital to their economic health. "In recent workshops across Africa, one hears repeatedly that the future economic growth of developing African countries is dependent upon the success of the small and medium-sized enterprises. From rural areas to the cities, the growth of small businesses will generate increased employment, wages, goods and services, and tax revenues. It is therefore in the direction of SMEs that developing countries should turn their attention."9

This is true in Asia as well. "Small and medium-sized enterprises have traditionally played an important role in economic development in Asia by creating a large share of new jobs, especially outside urban centres where the incidence of poverty is greatest. Thus, promoting SMEs can contribute to poverty alleviation and help to improve the distribution of income in a country."10 The situation is the same in Latin America.

Thus, despite globalization and technology, and perhaps in part because of globalization and technology, most equity markets have failed to generate significant capital development and growth. The challenges to equity market development are manifold and varied.

\section{Common Challenges to Equity Market Development}

Many stock exchanges around the world have not achieved the results that had been anticipated when they were established. Privatizations, even where they have been conducted over the domestic exchange, have certainly not served as a steady source of public offerings and growth. In some transition economies, the stock exchange experienced an initial spurt of growth as a result of the privatization process only to see the number of listed companies drop in subsequent years and growth stagnate and even decline. In other countries, privatizations either did not occur in any significant number, or took place outside of the exchange altogether.

\footnotetext{
${ }^{9}$ S. Cohn, 2004

${ }^{10}$ Seok-Dong Wang, 2003/2004. The Development of E-Financing Implications for SMEs, Bulletin on Asia-Pacific Perspectives. Note though that Asli Demirguc-Kunt and Thorsten Beck find that "while a thriving SME sector is a characteristic of flourishing economies, the results do not support the contention that SMEs accelerate growth and reduce poverty, calling into question the policy of directly subsidizing their development."
} 
Even in countries with a thriving small business culture, the companies, which are largely family-owned, continue to be reluctant to list on the exchange and new listings are few and far between. In addition, in many countries prime companies are listed on foreign markets, and local exchanges remain less attractive for foreign investors. These factors have produced domestic securities markets in vastly different emerging markets which look surprisingly similar, despite large differences in market capitalization. While the characteristics identified below may not be present in all markets, as a general matter, they are typical of many emerging equity markets and frequently represent both the cause and effect of one another.

Many emerging markets operate with low levels of transparency, poor information disclosure and weak corporate governance. In contrast, robust disclosure rules, monitoring and enforcement, and information dissemination are positively associated with a vibrant equity market. ${ }^{11}$ Timely and credible company disclosure promotes investor confidence, thus encouraging investors to participate more actively in the market. Greater liquidity may attract additional listings, which in turn increase investors' access to trading opportunities. As a result, market activity may increase, and capital formation is facilitated. However, since outside investors are not the primary source of finance in emerging markets, the external demand for disclosure and market liquidity is lower than in developed economies, and there is not much pressure either on issuers or governments to provide better disclosure or to improve governance. $^{12}$ Moreover, in countries with poor investor protection and low economic development, where outside finance is expensive and better governance mechanisms may be unavailable or very costly, there is little incentive for companies to adopt better governance because it does not result in a lower cost of capital. ${ }^{13}$

In addition to low levels of disclosure, transparency and weak corporate governance, stock exchanges in many emerging markets tend to be characterized by a substantial lack of liquidity. While liquidity can be measured in different ways, as a general matter, a liquid market is one in which there is a reasonable amount of turnover or trading, and where large transactions can take place quickly and efficiently. Emerging stock markets typically have very low turnover, with only a few companies responsible for a large percentage of the total trading that takes place. In Chile, for example, the annual turnover ratio of listed companies is lower than ten percent annually. In Brazil, ten companies account for more than 50\% turnover and 100 companies account for $99 \%$ of total trading. In Mexico, almost all of the trading is conducted in the shares of a few dozen large international companies. ${ }^{14}$

Accompanying the low levels of liquidity are low percentages of free float (the percentage of shares available for sale to the public). Thus, even those companies that decide to go public only offer a small percentage of their shares for

${ }^{11}$ Bushee and Leuz 2005

${ }^{12}$ Frost, Gordon and Hayes 2002

${ }^{13}$ Doidge, Karolyi and Stulz 2004

${ }^{14}$ Financial Times, April 12, 2005 
sale. For example, in Brazil, the free float is only approximately 20 percent, even though there are over 400 listed companies. In Columbia, the free float is about 10 or 15 percent, and in Chile, it is approximately 36 percent. The low level of free float contributes to the limited liquidity.

Ironically, the very absence of a healthy capital market - the poor disclosure and transparency, and low levels of liquidity and free float -- can itself discourage issuers and investors and thus contributes to a self-perpetuating cycle which presents a challenge for development. Weak, shallow markets without much liquidity are not attractive either to issuers or investors. Issuers will not find such markets to be an efficient source of capital and are likely to continue to find bank financing to be less expensive than the market, particularly when the issuer may have a long standing relationship with a particular bank. Investors, especially foreign investors, will not find many investment opportunities in such markets, and may well be worried about the risks they are assuming in investing in a market with little transparency or depth. Indeed, "the size, depth and liquidity of securities markets has clearly been found to correlate directly with the quality of the legal protections given shareholders." 15 Weak secondary market mechanisms are thus a key constraint on primary market activity.

Along with small and weak markets comes a limited investor base. Emerging markets, which typically have low levels of savings, generally do not have a large middle class that can constitute a widely diversified investor base providing significant participation from both retail and wholesale investors. In recent years, however, the institutional investor base has grown considerably, particularly in Latin America. However, these investors may find only limited opportunities in the domestic market. Countries frequently impose stringent restrictions on the range of products in which institutional investors may invest, requiring them either to invest only in domestic listed issuers or issuers with an investment grade credit rating, for example. In addition, institutional investors generally will only invest in issuers of a certain size in order to obtain the benefits of diversification and to keep the costs of portfolio monitoring under control. Thus, even in those countries where an institutional investor base has recently developed, there is not a ready pool of capital sufficient to attract small companies. Institutional investors thus have not contributed to the development of the market to the extent one might expect. ${ }^{16}$

Emerging economies are grappling with very basic issues as they endeavor to improve the quality and timeliness of information and increase the level of liquidity in their nascent securities markets. Investors in these markets may not be familiar with the risks and benefits of investing in securities or with the importance of demanding adequate and timely disclosure. The absence in many countries of an active investor base consisting of pension funds, insurance companies and collective investment schemes, as well as retail investors experienced in equity investment, is a challenge for emerging market authorities seeking to raise awareness among potential

${ }^{15}$ Coffee 1999

${ }^{16}$ See, Latin American Shadow Financial Regulatory Committee, 2005 
issuers of the role of the securities market in the economy and the viable alternative it can provide for funding business expansion. ${ }^{17}$

In addition, in emerging market economies, the securities regulator is typically poorly resourced and has only limited authority, especially as compared to the central bank or even an independent bank supervisor. The limited powers and resources of the securities regulator lead to significant shortcomings in its ability to oversee the markets, supervise market participants, and enforce issuer compliance. The securities market thus may not have the reputation for fairness and integrity that comes with strong oversight and enforcement. While this phenomenon is not limited to emerging markets, the disparity of the resources and the authority between the central bank and the securities regulator may be even greater in an emerging market than in a developed market.

While these characteristics present significant challenges to capital market development and economic growth, they are not insurmountable impediments. Although legal and regulatory measures cannot overcome all of these difficulties, and many other factors, including, primarily, the macro-economic environment, are critical, an appropriately designed and effective legal and regulatory framework can help to encourage market growth and to increase access to finance for all companies, including small and medium sized enterprises. We discuss below such a 'basic' legal and regulatory framework.

\section{Basic Legal and Regulatory Framework}

\section{A. Necessary vs. Nice}

Law and regulation establish the basis for the successful operation of a primary market for securities so that companies may have confidence in raising funds through the market when macroeconomic conditions are conducive for public offerings of quality securities. The market will only grow if basic legal protections are available to provide both domestic and foreign investors with confidence to invest. Investors need to be assured - or at least have a minimal level of confidence -- that their funds will not be lost as a result of fraudulent practices or unchecked insider dealing, and that they will be able to participate fairly in benefits that may arise from the success of the business or a possible change in control.

Taking into account the typical characteristics of many emerging markets, the obstacles to development that they face, and the difficulty of competing with global markets, policy makers should focus on the development of a primary market that can provide capital to small and medium sized domestic companies, and the related reasonable legal and regulatory framework. Legal and regulatory reform should not seek to replicate the regulatory environment in more developed markets but, instead, should concentrate on what is "necessary" rather than what would be "nice." Most important is ensuring legal certainty, and providing clearly expressed and readily

\footnotetext{
${ }^{17}$ Investor Education Report by IOSCO Emerging Markets Committee, January 2003
} 
understandable regulation that is accessible and easy to comply with and to enforce, especially given resource and other constraints. In considering what laws and regulations should be introduced to stimulate access to primary markets, there is a need to have regard to the stage of development of the securities market in the country in order to ensure that the laws will be a good fit in the existing legal framework and cultural environment.

It is not essential to introduce rules that reflect international best practice in one step if the rules are not relevant for the efficient conduct of the market or if the market is not sufficiently mature to absorb them. It is important for the country to develop a program of reform that will facilitate development by striking a balance between changes that are necessary in order to move towards best practice and not making too many changes that exhaust the market's appetite for reform and impede development. It is desirable to promote a program that will permit relevant actors in public and private sectors to move in the same direction at the same time over a reasonable timeframe that adapts to the current circumstances. It is a matter of balancing the desire to foster entrepreneurial activity against the need to adequately protect investors in the primary market. It may also be relevant to consider regional differences where laws are to be harmonized to promote regional initiatives and ensure that new rules will dovetail readily with the rules of nearby markets where linkages or alliances are likely to be forged in the future.

\section{B. Minimum rules and standards required to support the market}

While capital markets still form a small and relatively insignificant portion of the economy in many emerging markets, this is not a reason to avoid funding reform efforts. "Developing-country equity markets are small and often insignificant precisely because they are poorly regulated." 18 Without basic information disclosure and confidence in their ability to enforce their rights, investors will be unwilling to risk investments in stock market, or will discount the price of the companies whose securities they purchase, stronger companies will refrain from listing or go elsewhere, and the market will remain small.

A basic legal and regulatory structure is necessary to provide investors with the confidence to trade at arms length in a market where they lack information and risk expropriation by majority owners, and to permit firms to take on anonymous dealings and obtain outside funding from banks or investors. ${ }^{19}$ Disclosure and transparency help enhance the honesty and integrity of the securities market, thereby promoting the confidence of both investors and issuers. For this reason, disclosure is critical, and is the basis on which developed securities markets are regulated. "By focusing on market integrity and full disclosure, the regulatory system can foster growth and development without running the risk of becoming out-dated and unresponsive.” 20 The oft-cited research by La Porta et. al., concluding that "what

${ }^{18}$ P. Henry and P. Lorentzen 2003

${ }^{19}$ McMillan and Woodruff 2002

${ }^{20}$ Mann 1993 
works in securities laws” is mandatory disclosure requirements and a simple

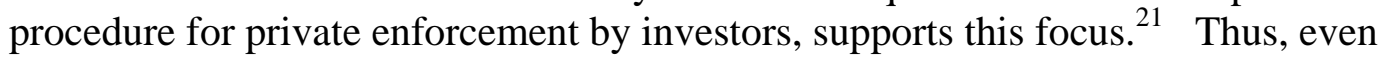
without targeting small and medium sized companies directly, by creating a better business environment where disclosure is more robust, commercial transactions for all firms, including small and medium sized ones, will be improved. ${ }^{22}$ A basic legal and regulatory framework that relies on disclosure and enforcement is a necessary foundation for all forms of primary market development, including both traditional public offerings and listings on the organized exchange and alternative forms of finance including private placements and private equity.

\section{Disclosure}

Minimum standards of disclosure, and the related accounting and auditing framework, are therefore critical to the development of a primary market. Required disclosure should encompass key financial and non-financial information, including the identity of the ultimate beneficial owner, all material events, and all related party transactions as these are frequently a key source of self-dealing, tunneling and expropriation. In developed markets, disclosure traditionally has centered on periodic disclosure, such as annual, semi-annual and quarterly reports, complemented by a requirement for prompt disclosure of price-sensitive information. However, with the development and spread of technology, the trend is toward requiring "continuous disclosure,” which calls for immediate disclosure of all material information.

Disclosure requirements are critical not just for securities that are offered publicly and traded over formal stock exchanges, but also for private offerings conducted outside of the formal exchange process. Disclosure requirements help diminish the risk that an investor assumes in making an investment outside of the exchange. As long as the disclosure is adequate, a sophisticated investor should be able to understand the risk involved and make its own determination as to the ratio of risk to reward that it can tolerate. ${ }^{23}$

Disclosure requirements are most effective when surrounded by a supportive infrastructure. The legal and accounting infrastructure must be in place, investors need to be capable of understanding the disclosures, politicians and media need to support a disclosure based system and not have unrealistic expectations, controlling shareholders (whether government or families) must adhere to the disclosure principles, financial statements have to be prepared and audited in accordance with high quality standards, and regulators must be credible, knowledgeable and have

\footnotetext{
${ }^{21}$ LaPorta, et.al., 2003. See, also, Blommestein, 2003, in which he states that confidence in a capital market derives from investor assurance that the rules are "fair, equitably applied and effectively enforced;" that "there is adequate disclosure about the financial condition of a public company, prohibition of selfdealing by insiders ... . and adequate arrangements for governance and representation;” and that public companies and their gatekeepers adhere to strict ethical standards.

${ }^{22}$ Demirguc-Kunt and Beck 2004

${ }^{23}$ A viable enforcement regime also reduces the risk.
} 
adequate enforcement powers and remedies. ${ }^{24}$ Obviously, this is a tall order. For these reasons, the disclosure requirements must be simple and easy to enforce. A legal reform strategy should carefully choose legal rules whose meaning can be understood and whose purpose is appreciated by domestic law makers, law enforcers, and economic agents who are the final consumers of these rules. ${ }^{25}$ "The strategy for reform is not to create an ideal set of rules and then see how they can be enforced, but rather to enact the rules that can be enforced with the existing enforcement structure." ${ }^{26}$

\section{Enforcement}

To be credible and effective, therefore, disclosure requirements must be enforced. "Again, it is not only the laws, but their enforcement that affects the ability of firms to attract external financing and, consequently, the degree of general financial development."27 Enforcement includes both ensuring there is compliance with disclosure requirements as well as prosecuting prohibitions against fraud and self-dealing. The regulator must be sufficiently independent to investigate alleged violations and impose fines and other administrative sanctions where contravention of the rules is established. Where civil or criminal action is taken through the courts, it must be timely, before judicial officers who have been trained in commercial proceedings and are free from bias towards government or influential commercial business. It may be that commercial arbitration and less expensive and more informal alternative dispute resolution mechanisms need to be introduced to determine disputes in an informed, timely and unbiased manner.

However, enforcement does not need to be effected through formal litigated actions. Even in the highly litigious United States, "more enforcement occurs through informal contacts, warnings, and administrative enforcement than through litigated actions. If the SEC is skeptical of a company or its disclosures, it can exercise very practical, but low-visibility, sanctions, such as simply failing to clear or declare effective a registration statement.,28

Enforcement responsibilities do not necessarily belong solely to the regulator or the government. The private sector can play a very important - and perhaps even more important - role. Indeed, research has shown that private enforcement matters at least as much as public enforcement for the development of securities markets. "Securities laws matter because they reduce the costs of private contracting and litigation rather than provide for public regulatory enforcement. That is, laws that facilitate the private enforcement of the law matter the most, especially in less

\footnotetext{
${ }^{24}$ Cameron 2003. The importance of developing a qualified accounting/ auditing profession with real entry standards is integral to ensuring that the legal and accounting infrastructure is in place, but is beyond the scope of this paper.

${ }^{25}$ Berkowitz, Pistor and Richard 1999

${ }^{26}$ Lopez-de-Silanes, 2000

${ }^{27}$ Berglof and Claessens 2004

${ }^{28}$ Coffee 2002
} 
developed countries.”29 ${ }^{29}$ Thus, while to a certain extent, regulatory enforcement can compensate for weak courts, an effective judicial system also serves to complement and reinforce the role of regulator.

In light of the ineffectiveness of enforcement in many emerging markets, where regulatory authority is limited, investors have few rights, legal institutions are weak, and the financial press is inactive if it exists at all, enhanced disclosure requirements may, not be sufficient to promote market development. ${ }^{30}$ In such countries, a greater level of prudential oversight in the form of corporate governance requirements may be warranted. While corporate governance reform alone will not make the market grow, its absence may in fact impede market development.

Research has shown that companies can partly compensate for ineffective laws and weak enforcement by establishing good corporate governance and providing credible investor protection. ${ }^{31}$ Increased corporate governance requirements provide confidence to minority investors. ${ }^{32}$ Thus, while a range of measures could be mandated, the specific requirements appropriate in a particular market will be those that, in light of the particular market context, would be likely to increase investor confidence.

In the next sections of this paper we discuss legal and regulatory mechanisms for improving primary market access aimed at two different targets: one looks at listings on the formal organized exchange, and the other looks at alternatives to primary market finance outside of the formal regulated exchange.

\section{Listing Fundamentals}

\section{A. Why Companies Do and Do Not List}

In considering what can be done from a legal and regulatory perspective to encourage companies to list on a regulated securities exchange in an emerging market economy, it is instructive to examine what motivates companies to list in addition to identifying specific disincentives that may exist. Potential public offerings may be drawn from companies that are controlled by government, the founder of the business, or the family of the founder.

There are a number of reasons that a government may choose to privatize a state owned enterprise through making a public offering. These include raising funds to reduce government debt, pursuing a government policy of relinquishing public

\footnotetext{
${ }^{29}$ Lopez-de-Silanes 2004 "The development of capital markets depends crucially on laws that facilitate enforcement and the improvement of court procedures that allow for a more efficient dispute resolution." ${ }^{30}$ Lopez-de-Silanes 2000

${ }^{31}$ Klapper and Love 2002. John Coffee argues, in fact, that a desire to "bond" to higher standards of disclosure and corporate governance is a key reason why issuers from emerging markets seek to list their shares on global markets. "By opting instead for a higher disclosure regime, the migrating firms maximize their share price and become able to raise additional equity at lower cost." Coffee argues there's a bonding effect attracting the prime issuers, not just a search for liquidity and market segmentation. Coffee, 2002

${ }^{32}$ F. Lopez-de-Silanes, 2000
} 
ownership of key assets, and, particularly where the government is to continue to hold a significant stake in the company through staged privatization, opening the company to management expertise outside the public sector in order to create greater efficiencies and increase profitability. ${ }^{33}$ Through listing on the exchange, a privatized state owned enterprise is exposed to greater competition and public scrutiny and can also boost private sector development by providing smaller exchanges with quality blue chip shares for secondary trading, thereby increasing total market capitalization of the exchange, and furnishing pension funds, collective investment schemes and individual investors with a broader array of investment choices.

Companies in the private sector pursue a rather different set of objectives when they decide to enter the capital market. They are seeking to raise equity for business expansion through initiating new ventures, making acquisitions or upgrading equipment. They may be looking to reduce the costs of outside finance and retire existing debt by raising funds at a lower cost or on more competitive terms, or to tap an alternative source of funds rather than continuing to rely on retained earnings, bank borrowings or increased equity contributions from family and friends. Alternatively, a company may need to attract long term financing which is not available to it through the banking sector, or wish to create an exit mechanism for existing shareholders (such as private equity investors or disenchanted family members), or to enhance the company's reputation and thereby seek to gain a competitive advantage by signaling that they are of sufficient size and quality to list or to attract higher quality managers. ${ }^{34}$

Disincentives to listing faced by state owned enterprises in emerging markets include inadequate secondary market mechanisms (including transparency and liquidity) as described above, political opposition to privatization of ownership of certain strategic assets, a private sector that is not sufficiently mature to be able to absorb a large public offering of securities, lack of profitability or a perceived inability to generate sufficient profits to make the company attractive to potential investors, and poor governance practices (for example poor quality management, financial reporting and internal controls), which do not inspire confidence in potential private sector investors. $^{35}$

The high cost of external finance, high costs of making an initial public offering (underwriting fees, accounting and legal fees, brokerage charges, printing and advertising costs, and listing fees) and the expense of meeting ongoing governance requirements for public companies (financial and significant event disclosures, internal financial controls, composition and functioning of the board) can

\footnotetext{
${ }^{33}$ Partial privatization of a state-owned company, while increasing market capitalization, may not contribute to economic efficiency and may even lead to undesirable practices, such as regulatory forbearance. Privatization through sale to a multinational strategic investor may, however, lead to complete integration of the privatized company into the foreign investor, and the loss of the potential local listing.

${ }^{34}$ There is a great deal of academic literature on why firms go public. See, e.g., I. Welch and J. Ritter, 2002. See, also, literature review in J. Ritter, 2005.

${ }^{35}$ See discussion in forthcoming World Bank paper by Yongboem Kim: The Links between Privatisation and Stock Market Development in the People's Republic of China
} 
provide strong disincentives for a private sector company to list. Costs and expenses of this nature can be prohibitive for smaller enterprises relative to their size. Other obstacles include lack of understanding by entrepreneurs of the availability of the primary market for accessing finance, the potential for the founder to lose absolute control over the company and concerns over greater transparency.

In many emerging markets, the corporate sector is dominated by companies with a strong controlling shareholder. Many companies, when they are not controlled by the State itself, are controlled by individuals or families who frequently are also the company's founder. "For developing countries, the average firm is majority controlled. . . . Large family owners are the norm not only in East Asia, but around the world." ${ }^{36}$ Controlling shareholders typically simply do not want to relinquish control of the companies that they dominate. In Mexico, for example, medium-sized companies "tend to remain under the control of their founding families, who fund themselves with credit and do not have incentives to take them public."37 Research on family-controlled companies has demonstrated that frequently such companies are better managed and demonstrate higher performance than companies with a more dispersed ownership base. ${ }^{38}$ In emerging markets in particular, families can exert a meaningful control on management that might otherwise be lacking, particularly where an effective court system and a strong regulator may be absent ${ }^{39}$ A controlling shareholder is in a good position to run the company as it sees fit, and may well be able to raise necessary funds through pre-existing personal or political relationships. While this type of financing may inhibit the long term growth prospects of the company, in the short and medium terms, it may be sufficient.

The desire of many family-owned companies to remain as private companies and their reluctance to grow beyond reinvesting retained earnings and financing by family and friends can stem from many causes, including the concern over loss of control described above. In addition, the need for full disclosure of the company's financial position and to publish audited financial statements that accord with international standards can give rise to a higher tax burden and have a significant adverse impact on the company's profitability, and is thus a significant disincentive to obtaining a listing. ${ }^{40}$ Sometimes the founder does not want to assume the regulatory burden and costs of increased disclosure, particularly as these are not simply a one-

\footnotetext{
${ }^{36}$ T. Nenova, 2004 By way of example, in Brazil, almost 51 percent of all firms are controlled by individuals, and in Mexico, the ten largest shareholders in the 40 largest companies own more than $80 \%$ of their respective company's shares, and almost $70 \%$ of the shares of the 60 most actively traded companies are held by controlling shareholders.

${ }^{37}$ Financial Times, April 12, 2005

${ }^{38}$ Andersen 2004

${ }^{39}$ T. Nenova, 2004

${ }^{40}$ In countries as diverse as India, Colombia and Kenya, endeavors have been made to overcome companies' reluctance to make full financial disclosure by offering fiscal incentives to companies that list. Measures include lower income tax rates and exemptions from capital gains taxes on transfers of shares on exchange but rarely provide a moratorium on taxes properly payable in past years. While in the short term they can be effective in encouraging listing, tax incentives often have undesirable side effects, including distorting the country's tax revenue base and being readily open to abuse.
} 
time expense but an ongoing cost of doing business as a public company. ${ }^{41}$ Sometimes there is simply a cultural reluctance to disclose information that may appear to be personal in nature. ${ }^{42}$ In some markets, it may in fact be dangerous personally dangerous - to disclose information about yourself and your company. Of course, none of these reasons is necessarily exclusive and there may be considerable overlap. $^{43}$

Many impediments to listing can be mitigated or removed altogether through education and training initiatives and by legal and regulatory reform. But alleviation of perceived obstacles is not of itself capable of bringing public or private sector companies to list on the exchange because the obstacles, while serious, are in fact incidental to the key incentives motivating companies to list. Recent experience in Korea provides evidence of this.

In 2005, the Korean government conducted a survey on costs incurred by public companies, with a view to investigating causes of sluggish activity in the stock market. $^{44}$ The survey found that 40 percent of listed companies do not see great advantages in being public. For example, 19.1 percent of listed companies consider that the costs are higher than the benefits of remaining public, and 20.9 percent see no net benefits.

Most listed companies in Korea also raised serious concerns over everincreasing compliance costs. More specifically, they indicated that the most burdensome regulations are: (i) disclosure rules (60 percent), (ii) litigation risks (50 percent), and (iii) requirements for listing maintenance (42 percent). The total compliance costs in Korea are estimated to be far lower than those in the US; however, the relative amount to the market capitalization and GDP is comparable. As expected, since the compliance costs are a fixed cost, smaller companies tend to be affected more negatively as the regulatory burdens increase. ${ }^{45}$

\footnotetext{
${ }^{41}$ One way to overcome the disincentive to list caused by the increased disclosure and governance requirements is to impose those requirements on all companies - not just listed companies - above a certain size, and a number of countries, including, for example, Sri Lanka and Tunisia, have done so. However, it is important to ensure that such requirements are then enforced.

${ }^{42}$ The different approaches taken by developed markets to requiring disclosure of executive compensation amply demonstrates these divergent cultural sensitivities.

${ }^{43}$ A reluctance to disclose is not unique to emerging markets. In the United States, for example, when the SEC proposed to increase disclosure for companies traded on Nasdaq's over-the-counter Bulletin Board, a significant number of companies delisted, rather than take on the new disclosure burden. Bushee and Leuz, 2004

${ }^{44}$ The Korea Securities Research Institute, "Policy Recommendations for Reducing Compliance Costs of Public Companies,” June 2005. The data for listed companies were collected from 201 companies (113 in KSE and 88 in KOSDAQ) out of 1,566. In addition, focused interviews with senior mangers from 20 companies in each market were carried out to complement the survey and to estimate the absolute amount of compliance costs.

${ }^{45}$ To a certain extent at least, this is expected: those companies that do not list are most likely to complain about the burdens, and some of those companies might in fact not be able to list should they desire to do so.
} 
The survey also investigated private companies. The reasons for remaining private are similar to the cost concerns articulated by public companies. They include: (i) risks of interference in the management by new shareholders (42 percent), (ii) burdens of meeting requirements for listing, both initially and on an ongoing basis (34 percent), and (iii) contingent costs from unexpected litigation (20 percent).

The survey results clearly show the challenges that governments in emerging markets can face in undertaking capital market reforms. The reform measures bringing new and strengthened regulations, such as enhanced disclosure and tighter listing requirements, are perceived as burdening firms with increased costs, while their benefits are estimated to be less significant and less immediate in impact.

\section{B. Listing Standards and Disclosure Rules}

Regulators and exchanges may alter exchange listing standards or public offering disclosure requirements in an effort to attract listings to the domestic organized exchange. Eligibility standards set by exchanges for companies to list initially and to maintain their listing generally set minimum requirements for a company to qualify for listing on the exchange (such as its record of profitability, number of shares and shareholders, market capitalization, free float, shareholder voting rights), and establish ongoing requirements the company must meet to remain listed (minimum market capitalization, minimum level of trading in its shares, number of shareholders, free float, compliance with the disclosure requirements of the law and the listing rules). Regulators and exchanges can sanction companies which fail to comply with ongoing requirements by suspending their securities from trading or ultimately by delisting their securities altogether.

Where a country's laws do not provide sufficient investor protection, private contractual arrangements can be effective. Exchanges can impose standards through listing rules, and companies can voluntarily agree with their shareholders to maintain higher governance standards than the law actually requires. ${ }^{46}$ Indeed, recent research in Korea suggests that, even in the absence of a strong environment for legal enforcement, firm value can be enhanced by listing on an exchange where governance standards are perceived to be strict. ${ }^{47}$

Disclosure rules for public offerings require a company to disclose all information that is relevant to the making of an informed decision to invest in its securities, and extend liability for damages to directors and other persons involved in the issue of the prospectus in which there is a materially false or misleading statement or from which a material matter has been omitted. ${ }^{48}$ Ongoing disclosures by listed companies generally include periodic disclosure of financial information, current

\footnotetext{
${ }^{46}$ Jordan and Lubrano 2002, Klapper and Love 2002.

${ }^{47}$ Dewenter, C. Kim, U. Kim, W. Novaes, 2005. This is consistent with the "bonding” effect described by Coffee, 2002. See, also, the discussion about the Novo Mercado, infra.

${ }^{48}$ Support for a general disclosure requirement is found in the IOSCO Objectives and Principles of Securities Regulation, 2003
} 
disclosure of price sensitive information, and disclosure of information with respect to transactions to be entered into with related parties. International best practice dictates that disclosure should in all cases be full, timely and accurate. The company's financial statements should be required to be prepared in accordance with internationally recognized financial reporting standards and annual financial statements audited in accordance with internationally recognized auditing standards.

In countries where there is high ownership concentration among listed companies, it is desirable for directors and key executives of a company and their families to be required to give notice of dealings in the company's securities and for substantial shareholders (generally a person and his associates who have an interest in $5 \%$ or more of the company's shares) to give notice of their shareholdings and any changes in their shareholdings.

The private sector frequently plays a gatekeeper role in ensuring that listed companies comply with their disclosure obligations. Accountants and auditors are responsible for confirming that a listed company's financial statements are prepared and audited in accordance with the required standards. Licensed market intermediaries underwrite new issues and provide independent valuations of company assets for the purpose of enabling investors to assess the pricing of an issue. It is important for investors who rely on the activities of market intermediaries in connection with primary offers to have the protection of adequate capital requirements against which they can have recourse in the event of fraud or negligent misconduct. ${ }^{49}$ Lawyers advise companies that are listed or to be listed on the contents of a prospectus for a public offering and can generally be liable for material inaccuracies or omissions in the prospectus unless a due diligence defense is available and they can bring themselves within it.

Regulators and exchanges have tried to encourage public and private sector enterprises to access the primary equity market by reducing the time and cost to issuers of raising funds by public offerings through streamlining the disclosure rules while maintaining investor protection. In addition, attempts have been made to promote greater access by establishing alternative markets with listing standards that are either higher or lower than those of the formal organized exchange, which, as can be seen below, have had mixed success. While initiatives such as these have been useful, they can only go so far in promoting capital market development more broadly, especially in the absence of minimum rules and standards that we suggest are required to support a viable primary equity market in an emerging market.

\section{Dealing with Delistings}

A necessary part of encouraging listings and promoting the market is to ensure that companies that are not compliant with listing standards or disclosure standards are delisted, and that minority shareholders are protected in that process. The

\footnotetext{
${ }^{49}$ Capital adequacy requirements for market intermediaries need to recognize the business operations and
} address risks to which an intermediary is subject in both primary and secondary market activities. 
regulator or the exchange is responsible for monitoring compliance with the listing rules and has power to suspend a company for violating the rules and ultimately to delist the company's securities. Companies are generally delisted for breaches of the rules that impact on the business of the exchange and have a negative effect on its reputation or brand rather than for corporate governance shortcomings. A company may be delisted because it fails to meet ongoing minimum liquidity or market capitalization requirements or does not pay its annual listing fees. It is much rarer for a company to be delisted because it does not file audited annual financial statements within the time prescribed or does not have the required number of outside directors or a properly constituted audit committee.

A company may seek to delist on its own initiative when it ceases to have the required minimum number of shareholders or percentage of free float following a takeover, or a merger, reconstruction or amalgamation, or a share buy-back, or when it becomes insolvent. A controlling shareholder may be motivated to delist the company because it is no longer profitable, or has squandered its growth potential, or is looking to reduce the costs of complying with the higher disclosure and governance requirements that would have to be met by it as a listed company. In the United States, many smaller companies have delisted voluntarily in apparent response to additional requirements of the Sarbanes-Oxley Act and a desire to avoid the costs of meeting those requirements which impose a disproportionately large compliance burden on them. ${ }^{50}$

New capital raisings and company listings on formal exchanges provide a boost to the capital market but it has to be recognized that these activities involve a number of independent experts and advisers, are highly regulated and the costs borne by issuers can be considerable. Companies have other means of raising capital available to them, some of which may be less costly with fewer regulatory requirements to meet.

\section{Developing Alternatives to Listings on the Formal Organized Exchange}

\section{A. New Markets}

In some countries an exchange has different boards or market tiers and some countries support several exchanges that compete by having different listing criteria generally in an endeavor to facilitate access to equity capital for smaller enterprises. In some cases different market segments extend to over-the-counter markets where securities trade on an unlisted basis. The availability of over-the-counter markets can also make delisting more viable because shareholders have a trading venue for valuing and dealing in their shares following delisting from an organized exchange.

Competition between exchanges creates niche markets which meet the demands of different types of issuers. ${ }^{51}$ Exchanges with high listing standards attract

\footnotetext{
${ }^{50}$ Leuz, Triantis and Wang 2004

${ }^{51}$ Coffee 2002
} 
blue chip issuers whereas exchanges with lower standards attract lower quality companies. $^{52}$ By enhancing its listing rules an exchange can improve investor protection in the same way as cross listings do (individual companies adopt higher governance practices which provide greater protection to minority shareholders and this results in turn in greater liquidity, improved share price and lower cost of funds). Enhancing listing standards can also slow migration of top companies to overseas exchanges (e.g., the NYSE) where companies meeting the highest standards attract the attention of international investors.

The last decade has seen an emergence of new markets, which are trying to duplicate the success and viability of the Nasdaq, and which cater to new and highgrowth companies. The track record of these new exchanges has been mixed, with some resounding failures such as the Neuer Market in Germany, and some which have fared better, such as the AIM in the United Kingdom and Kosdaq in South Korea. $^{53}$ Although these markets have pursued broadly similar strategies, there are distinct differences in their focus and context which have affected the outcome of their efforts. One major determining factor has been timing - the failure of several markets occurred during the bursting of the dot-com bubble, and it is possible that they would have done better under different circumstances.

Table 1: Summary of selected alternative markets

\begin{tabular}{|l|l|l|l|l|}
\hline Exchange & $\begin{array}{l}\text { Launch } \\
\text { date }\end{array}$ & $\begin{array}{l}\text { Focus and } \\
\text { target } \\
\text { companies }\end{array}$ & Regulatory approach & $\begin{array}{l}\text { 3-year index } \\
\text { performance, end } \\
\text { 2002-end 2005 }\end{array}$ \\
\hline AIM (UK) & 1995 & $\begin{array}{l}\text { Domestic and } \\
\text { foreign, small } \\
\text { growing } \\
\text { companies, } \\
\text { all sectors }\end{array}$ & $\begin{array}{l}\text { Less stringent than LSE } \\
\text { official list }\end{array}$ & $\begin{array}{l}\text { FTSE AIM index, } \\
+73 \%\end{array}$ \\
\hline $\begin{array}{l}\text { GEM } \\
\text { Kong }\end{array}$ & 1999 & $\begin{array}{l}\text { Domestic and } \\
\text { mainland } \\
\text { China, } \\
\text { companies } \\
\text { with growth } \\
\text { potential, } \\
\text { informed } \\
\text { investors } \\
\text { only, mostly } \\
\text { high-tech }\end{array}$ & $\begin{array}{l}\text { More stringent on } \\
\text { disclosure and } \\
\text { governance, less } \\
\text { stringent on track } \\
\text { record/profitability } \\
\text { issues }\end{array}$ & $\begin{array}{l}\text { S\&P/HKEx GEM } \\
\text { Index, +6\% }\end{array}$ \\
\hline $\begin{array}{l}\text { Neuer } \\
\text { Market }\end{array}$ & 1997 & $\begin{array}{l}\text { Domestic, } \\
\text { new and } \\
\text { innovative } \\
\text { companies, } \\
\text { high-tech } \\
\text { sector }\end{array}$ & $\begin{array}{l}\text { More stringent } \\
\text { disclosure and } \\
\text { governance } \\
\text { requirements than main } \\
\text { board, lower track } \\
\text { record requirement }\end{array}$ & More stringent than the \\
Domestic, & IGCX (Corporate \\
\hline Novo & 2000 & & Closed in 2002 \\
\hline
\end{tabular}

52 Chemmanur and Fulghieri 2003

53 Appendix 1 sets forth statistical information about selected alternative markets. 


\begin{tabular}{|l|l|l|l|l|}
\hline $\begin{array}{l}\text { Mercado } \\
\text { (Brazil) }\end{array}$ & $\begin{array}{l}\text { (first IPO } \\
\text { in 2002) }\end{array}$ & $\begin{array}{l}\text { companies } \\
\text { committed to } \\
\text { higher } \\
\text { corporate } \\
\text { governance } \\
\text { standards, all } \\
\text { sectors }\end{array}$ & $\begin{array}{l}\text { Brazilian Corporations } \\
\text { law }\end{array}$ & $\begin{array}{l}\text { Governance) Index, } \\
+256 \%\end{array}$ \\
\hline $\begin{array}{l}\text { Kosdaq } \\
\text { (Korea) }\end{array}$ & 1996 & $\begin{array}{l}\text { Mostly } \\
\text { domestic, } \\
\text { SMEs, high- } \\
\text { tech and } \\
\text { knowledge } \\
\text { based } \\
\text { ventures }\end{array}$ & $\begin{array}{l}\text { Less stringent than the } \\
\text { Korea Stock Exchange }\end{array}$ & $\begin{array}{l}\text { Kosdaq Index, } \\
+58 \%\end{array}$ \\
\hline
\end{tabular}

In Germany, the Deutsche Borse AG founded the Neuer Market in 1997 in an attempt to enable young and innovative companies to obtain equity capital ${ }^{54}$. In order to gain investors' trust, the listing requirements in the new market were designed to be higher than those for the "official trading" on the Deutsche Borse. They included the use of at least two designated sponsors, higher equity capital and issue market price requirements, quarterly reports and financial statements that complied with International Accounting Standards or US-GAAP to be published in German and English, and a six-month "lock-up" period following the IPO. These requirements were put in place specifically to address the perceived caution of German investors with regard to investing in stock markets and the absence of an "investment culture." Despite introducing higher standards, the market objective was to attract listings by firms which had a shorter track record and lower turnover than would be required for listing in the major market segments of the exchange.

The Neuer Market was very successful in its first few years, leading a marked change in German capital markets. Where in the 14 years before the opening of the Neuer Market, the average IPO proceeds amounted to the equivalent of about 2.2 Billion Euro, from 1997 on they mushroomed to reach 25.6 Billion Euro in IPO proceeds in 2000. Significant "underpricing" in the Neuer Market drew more and more investors, not only to the primary market where issue sizes were too small to satisfy the growing demand, but to the secondary market as well. Although institutional investors mostly stayed away from the market, the number of retail investors entering the market grew quickly, from 3.7 million before the Neuer Market began operations to 6.2 million in 2000. During the three years and one month preceding March 2000, the NEMAX-All-Share index which covered the new market increased by about $1636 \%$, outperforming the NASDAQ- 100 .

However, the index started to fall in 2000, reaching an all time low in October 2002 of about $4 \%$ of its March 2000 high. In market capitalization terms, the market fell from €234 Billion in March 2000 to €29 Billion at the end of September 2002. Beginning in 2000, the market was beset by earnings disappointments, followed by

\footnotetext{
${ }^{54}$ The description of the Neuer Market’s evolution is largely based on Burghof and Hunger, (2003)
} 
rumors of impending bankruptcies and culminating in actual insolvencies. In addition, there were recurring rumours of fraudulent activities by entrepreneurs of Neuer Market companies, which harmed the market's reputation irrevocably. Finally, the Neuer Market segment was closed and the companies that met the listing requirements were folded into the broader market.

The reasons for the dramatic decline of the Neuer Market include a narrow focus on high-tech companies, the lack of sophistication of both investors and the relevant regulatory authorities, and timing -- the Neuer Market took off just as the stock market bubble was beginning to inflate around the world. Another factor was a regulatory framework which, although it appeared robust, was quickly shown to be inadequate and unable to provide strong incentives for responsible corporate behavior.

The Alternative Investment Market (AIM) promoted by the London Stock Exchange (LSE) has taken a different approach than the Neuer Market, and was fortunate enough to have better timing. AIM was launched in 1995 to meet the needs of small growing companies, and applies a less stringent regulatory regime than that of the "official list" of the LSE. AIM has created a light touch regulatory environment that sets out to attract a broad set of companies from different sectors and focuses on the needs of institutional investors. It also relies on the stronger investment culture and regulatory capacity that prevail in the United Kingdom.

For a company to list on AIM, there is no minimum level of shares required to be held by the public, no trading record requirement, no prior shareholder approval for transactions requirement, and no minimum market capitalization. However, a company must appoint a nominated advisor (nomad) who is responsible, among other duties, for warranting to the LSE that the company is appropriate for AIM. The company's application for admission is pre-vetted by the nomad, not the LSE or the UKLA.

Since AIM opened, it has admitted more than 1900 companies and raised more than $£ 17$ Billion. While it too experienced some difficulties at the bursting of the high tech bubble, the FTSE AIM index has performed well in the last few years, going from a level of 602 at the end of 2002 to 1046 at end of 2005. AIM is considered to be the only truly effective second-tier market in Europe, and presents an alternative to listing on the Nasdaq for companies worldwide. This trend has strengthened since the adoption of the Sarbanes-Oxley Act in the United States, which has made it more expensive for smaller companies to list on the Nasdaq. Companies that list on AIM also do so because of the levels of institutional investment that it attracts, as compared with the United States where retail investors are dominant.

In Brazil, the Novo Mercado was introduced by BOVESPA in December 2000, and presents a different model altogether. It is a listing segment for companies that voluntarily decide to comply with corporate governance and disclosure 
requirements which go beyond the stipulations of Brazilian legislation. The main innovation of this market is that non-voting shares may not be issued. Since many of the companies currently listed on the BOVESPA either cannot (e.g., they have non voting shares on issue) or do not wish to comply with these requirements, the Novo Mercado introduced different corporate governance levels to accommodate companies which cannot meet the full Novo Mercado requirements. A company can belong to level 1 if it maintains a $25 \%$ free float, uses public offering mechanisms that promote dispersion of capital and takes on additional disclosure and reporting duties. To receive a level 2 classification, a company must adhere to level 1 rules, and also adopt a broader range of corporate governance rights and minority shareholder rights, including annual balance sheet disclosure according to US GAAP or IFRS, tag along rights for common shareholders, voting rights for preferred shares in certain situations. Currently, 18 companies are listed on the Novo Mercado.

After a quiet period, there has been an increase in the level of activity in the Brazilian market since mid-2004 to which the Novo Mercado appears to have contributed. In 2005 there were 20 new share issues, including 9 initial public offerings. All issuers have either been listed on the Novo Mercado or meet the higher corporate governance requirements of levels 1 and 2 on the exchange. The performance of companies listed on the Novo Mercado has also been encouraging. The IGC index (corporate governance index) which includes the 18 companies listed on the Novo Mercado together with the 47 other companies listed in levels 1 and 2 has risen by $43.7 \%$ in 2005, well outperforming the benchmark IBOVESPA index which registered a $27.7 \%$ increase in the same period.

In Asia, several markets have tried to emulate the Nasdaq model. Two important markets are KOSDAQ in Korea and the Growth Enterprise Market (GEM) in Hong Kong, founded in 1996 and 1999 respectively. KOSDAQ has a broad focus on knowledge-based ventures, high-tech companies and SMEs, and has different listing requirements for venture companies and non-venture companies. The listing requirements are simpler than those of the Korea Stock Exchange, and the government of Korea has diversified requirements and relaxed regulations for listing on the market so that large telecommunications companies and other similar firms can be listed as well. The total number of companies listed on the KOSDAQ has grown from 331 in 1996 to 879 in 2003, and the market capitalization has grown in that time frame from US\$6.3 Billion to US\$30.8 Billion, so that within a few years the market has grown to represent $10 \%$ of the Korean stock exchange value (as of 2003).

GEM in Hong Kong focuses more narrowly on companies with growth potential, and does not require a solid record of profitability for listing. GEM balances that by imposing more stringent listing requirements than other Asian second-board markets, and promotes itself as offering a "high growth, high risk" paradigm, appealing to professional and informed investors. GEM requires companies to use a "sponsor" for the first two years after listing, and has stringent disclosure and business practice rules that firms must adhere to. However, GEM has not performed as anticipated in the years since the dot-com bubble burst. The GEM 
index has underperformed in comparison with the Hang Seng index. In 2004, it rose by $1.9 \%$ in comparison with $4.5 \%$ for the Hang Seng. The market capitalization of the GEM is $0.8 \%$ of the main board, and the turnover ratio of $33 \%$ for GEM was lower than that of the main board at 51\%. In its peak years of 2000-2001, the number of listings on the GEM surpassed those on the main board; however, since 2002 that trend has reversed, and in 2005 ten companies listed on the GEM while 57 companies listed on the main board. ${ }^{55}$

Another model for promoting new and high-growth companies can be found in Israel. The small size of Israel's market has led many Israeli companies to focus on the global market instead, and many have listed their shares on foreign exchanges. Israel is third only to the United States and Canada in the number of companies listed on the Nasdaq. Israeli start-ups have raised more than $\$ 5.2$ billion in initial public offerings on the Nasdaq between 2000 and 2005. As of February 2006, 74 Israeli companies listed on Nasdaq had a combined market capitalization of $\$ 48.8$ billion in comparison with the total market capitalization of the TASE of \$ 122.6 billion (at end 2005). Since January 1999, Israeli start-ups have raised more than $\$ 5.8$ billion in IPOs and secondary offerings on foreign exchanges, $82 \%$ of which was raised on the Nasdaq.

The Nasdaq market has been the market of choice for Israeli companies for a number of reasons. The United States is the biggest equity market in the world, with a market capitalization and trading value far exceeding other prominent markets such as London and Tokyo. Such a large market attracts companies globally. Also, being a small country, with a small domestic market, many Israeli companies see their market globally, and therefore look to access their financing in a global environment as well, in a way that promotes their global visibility.

At least 15 Israeli companies have listed on the AIM market in the last couple of years, and a steady stream of additional companies is expected to follow. In addition, there are nine Israeli companies listed on the LSE, three on the NYSE and one on AMEX. Smaller companies are finding the legal and accounting costs associated with the Sarbanes-Oxley Act to be prohibitive relative to their current size. The AIM market targets smaller companies than the Nasdaq, and is less costly. Nasdaq estimates that the average market capitalization of Israeli companies listed on the Nasdaq is $\$ 670$ million, as compared to $\$ 373.7$ million on the LSE and \$47.5 million on AIM.

From the Israeli market's perspective, as of August 2005, there were 41 companies dual-listed on the Tel-Aviv Stock Exchange and on US exchanges, primarily the Nasdaq. The Israeli Parliament has recently approved an expansion of dual-listing on the TASE to London Stock Exchange Official List companies and NASDAQ SmallCap listed companies. In further trying to attract companies to duallist, Israel has exempted local investors from capital gains tax on their investments in TASE dual listed shares. The dual listing has expanded the universe of investment

${ }^{55}$ Hong Kong Exchanges and Clearing Limited, Discussion paper, January 2006 
opportunities available to Israeli investors, contributed to increased activity on the domestic market and raised the profile of the Israeli securities industry.

Israeli companies have listed abroad in order to take advantage of the larger pools of funds available outside the country, and lower cost of capital associated with highly liquid and efficient markets such as the Nasdaq. The Tel-Aviv Stock Exchange's performance has not suffered from this migration, and with many companies now dual-listing in Israel, the Israeli capital markets are gaining. Further, Israeli companies listed on the Nasdaq and elsewhere are important players in the Israeli economy, and their ability to grow by accessing foreign markets enables them to invest more in Israel, and create jobs and pay taxes there. However, this model is not without its risks. Israeli companies listing abroad are "small fish", without much influence on lawmakers outside the country, and therefore are vulnerable to changes in the regulatory environment (such as the Sarbanes-Oxley Act) which could have a negative impact on the allure of new listings and the costs to issuers of remaining listed on exchanges outside Israel.

While many emerging market economies have difficulty supporting one formal exchange with only one segment, the experience of different alternative market models for the financing of new and high-growth companies highlight the many different elements which have contributed to their success or failure and which can be useful considerations in thinking about promoting access to finance in emerging markets. A few general observations can be made: markets which narrowly focus on one sector are vulnerable to a downturn in that sector; active enforcement backed by a strong regulatory environment and regulatory capacity is crucial; a market which targets unsophisticated investors needs to be subject to more stringent regulation; a supervisory and advisory role, similar to the one played by "nomads" on the AIM market can be a helpful tool in keeping inexperienced companies on the right track; finally, under certain circumstances, the lack of a deep domestic market does not necessarily mean that smaller and new companies cannot successfully access financing on a primary market elsewhere.

\section{B. Private Placements}

Formal exchange offerings, whether on the primary stock exchange or on a second board or segment, are not, however, the only way companies raise funds, and, in fact, most companies do not rely on exchange financing or even on offerings to the public. In all countries, developed and emerging, the owners of most companies raise funds from their families, friends and trading partners, and then use their own equity for further financing. In recognition of this pattern, some developed markets have built a legal mechanism that permits companies to go beyond their limited circle in seeking funding, but does not entail the time or expense of making a public offering. This mechanism, the so-called private placement, can be very useful for encouraging growth and for addressing the incentives, preferences and market structure issues that are characteristic of primary market growth in many emerging markets. The US 
experience for example, "has clearly demonstrated both that the private placement markets can be successfully promoted as a valuable source of capital, complementary to the public markets, as well as that these markets can only properly develop in an environment of clear regulatory "safe harbors," under which both issuers and investors can operate with confidence." ${ }^{\text {. }}$

A private placement is a technique in which an issuer offers its securities to a restricted audience in exchange for funds. Because the offering is restricted in scope, it does not require the regulatory oversight necessary for investor protection in a public offering. It is therefore less timely and costly, and is well-suited for the needs of less established or lesser known companies with smaller capital requirements and limited resources. Similar to the market for bank loans, the terms of a private placement are typically negotiated between the issuer and the investors, who use contractual covenants to control their risk. However, maturities in a private placement tend to be longer than in a bank loan, and upon a possible default, it is easier and more typical for the parties to renegotiate the terms.

Historically, private markets emerged before public markets in developed economies. Indeed, a private placement market can serve as a filter for the public market. A private placement market allows riskier and newer companies to find financing outside of the public market which may have a base of inexperienced retail investors and is therefore better adapted to products with a safer profile. Private placements are well suited for companies seeking to bridge the financing gap between family and friends on the one hand, and the public markets on the other. It has been argued in fact that, in emerging markets there is "a pressing need for some form of registration exemption [or] modified process applicable to SMEs to enable them to raise capital in a quicker and less costly manner than the full registration process. ${ }^{, 57}$

Minimal legal and regulatory requirements apply to private placements. The principal requirement is that a legal or regulatory exemption from full securities registration be created. The rationale for this exemption is that the offering is being made to a limited audience and, therefore, the protections of the full panoply of securities laws are not necessary. The scope of that exemption, however, can vary, depending on the composition of the country's market. For example, an exemption may be created for offerings to a limited number of investors, or to investors who are deemed to be "sophisticated" and able to look out for themselves without the protection of the securities laws. These "sophisticated" investors are typically denoted as individuals with high net worth or as institutional investors of a certain type or size. Alternatively, an exemption may be created based on the size of the offering. ${ }^{58}$ What is key, though, is that the exemption be clear, certain, and complete. A clear legal and regulatory foundation is necessary to inspire confidence and attract issuers and investors. Absent certainty, the market will be confused and will not take

${ }^{56}$ Managed Fund Association, 2001

${ }^{57}$ S. Cohn, December 2004

${ }^{58}$ For example, Rule 504 of Regulation D under the US Securities Act of 1933 allows issuers to sell up to \$1million of securities without registration. 
advantage of the exemption. Without completeness, the exemption will not be sufficiently distinct from a public offering to accomplish the goal of bringing new issuers who may have difficulty with the hurdles of a public offering into the market.

In some countries, private placements are regulated to such an extent that they cannot easily be distinguished from a public offering. “... the greater the technical requirements, the more the conditions begin to look like a registered offering, the less the exemption will be utilized and SMEs will remain frozen out of the capital market."59 In India, for example, private placements can be listed and traded if the issuer has an investment grade rating. In that case, however, the full regulations applicable to listed companies apply and the benefits of a "private" vehicle may be lost. In France, private placements have been permitted only since 1998. The legal framework in which they are offered remains confusing, as laws on solicitation (“demarchage”) remain highly restrictive and geared to an exclusively public offering regime. ${ }^{60}$ Private placements in Africa are rare, where many countries lack a legal process that would allow companies to undertake limited public offerings without full registration. $^{61}$

An offering that qualifies for exemption from registration should be exempt from regulatory review and oversight. This is a significant factor in reducing the time and cost entailed in raising funds beyond family and friends. Fundamental anti-fraud requirements should apply, which require the issuer and controlling shareholder/ founder not to misrepresent or make any key omissions about the offering, and investors should be legally able to protect themselves by bringing an action for fraud against the issuer, the controlling shareholders, and the directors. While other requirements could be added, such as, for example, requirements that the issuer sell a minimum amount of securities within a fixed time period for the offering to be effective, the more requirements that are added, the less simple and attractive the mechanism.

\footnotetext{
${ }^{59}$ S. Cohn 2004

${ }^{60}$ Private placements in the UK are limited (as of Jan 2004, need to update), at least in part because of the complexity and burdensome quality of their regulation. In the UK, only "authorized” persons can "promote" products unless the content of the promotion communication has been approved by an authorized person or the communication is exempt from Financial Promotion Order. Under the Order, unlisted firms can raise equity capital directly, if the promoter knows the potential investor is "certified as a high net worth individual” or is a sophisticated investor. To be "certified” as a high net worth individual, an investor must obtain a certificate signed either by his employer or accountant, stating that he earns at least 100,000 pounds or has net assets worth at least 250,000 pounds excluding his primary residence, etc. to be qualified as a "sophisticated investor," the investor must be certified by an authorized person as sufficiently knowledgeable to understand the risks associated with the relevant description of investment. ${ }^{61}$ In the United States, in contrast, "the securities laws and regulations have been purposefully developed and refined over the last 25 years so as to clarify and expand the scope of which offerings qualify as private placements. The effect of these changes has been increased reliance by market participants upon the private capital markets, notably without detriment either to the public capital markets or to investors. Ready access to private capital has been a major engine of U.S. proprietary and technological developments.” Managed Funds Association 2001
} 
Private placements can be attractive to both issuers and investors. For issuers, as noted above, private placements have the advantage of relative speed and low costs as compared to a public offering. An issuer can reduce its dependence on bank financing, while engaging in a confidential transaction. Thus, to the extent that controlling shareholders/ founders are reluctant to submit to public disclosure obligations, a private placement can offer a relatively stable, long-term source of funds that does not require public disclosure or a loss of control. They also provide the issuer with an opportunity to build its reputation, and thus position it to enter the public markets in the future. For an investor, a private placement provides an attractive alternative investment opportunity, particularly where public equity markets are limited. From the investor's perspective, the private placement vehicle gives greater control over the investment and a better ability to assess risks. These are features that may well be lacking for an investor in a typical public emerging market. The attractiveness of the private placement can be enhanced if there is a regulated OTC market on which the private placement shares can be traded after an initial "restricted" period. In the United States, for example, the attractiveness of private placements was increased when the SEC created Rule 144A, a form of private placement to qualified institutional investors in which shares could subsequently be traded among other Rule 144A qualified institutional investors. ${ }^{62}$

\section{Other Alternatives}

Private placements are not the only alternative for firms seeking primary financing outside the public markets. Other alternatives include corporate debt offerings and securitization. Two other alternatives that deserve brief mention are special instruments and venture capital.

1. Special Instruments. It is possible to create a specialized vehicle tailored to the particular dimensions of the financial sector with the goal of promoting investment through the primary market, thereby both increasing access to finance for issuers and greater opportunities for investors. In many emerging markets, the securities market is hampered by both demand and supply side problems. On the demand side, the institutional investor base either is limited, or faces significant restrictions in the types of products in which it is permitted to invest. On the supply side, there is frequently a limited source of investments. Only a few companies are listed on the domestic market, and unlisted companies may pose unacceptable risks. A specialized or "mezzanine" vehicle, which is aimed at bridging the gap between unlisted SMEs and listed companies, and in which institutional investors are permitted to invest, could serve to break the logjam.

In Mexico, for example, the Mexican legislature has recently adopted a new securities law that allows for the creation of a special investment vehicle, a "sapi" or investment promotion group," that would give special protections to minority

\footnotetext{
${ }^{62}$ Another alternative is to create a small cap board for shares that had been placed privately, in which investors are alerted to the special risks involved, but the shares can trade on the basis of less stringent listing and reporting requirements.
} 
shareholders. ${ }^{63}$ This new vehicle would also be subject to fewer reporting requirements than public companies. Even though sapis would be permitted to list on the market, they would have a three year "grace period" until they are required to make full disclosure of their accounts. Because of the risks involved and the limited disclosure, investment in this new vehicle would be restricted either to institutional investors, or to private investors who have signed a waiver acknowledging that they understand the risks of the investment. Pension funds, however, which previously have been limited to investing in bonds, would be permitted to invest in the new vehicle. This new vehicle is expected to increase venture capital investment by creating an exit mechanism, build liquidity through increased pension fund investment, encourage listings, and protect minority shareholder rights. ${ }^{64}$

2. Private Equity. Another potential source of capital for issuers in emerging markets is private equity, or venture capital investment funds. However, private equity should not be considered as an antidote to regulated markets. Arguments that private equity would take off if "stifling" regulation were eliminated are specious. Indeed, "[i]f developing a strong public stock market is hard, developing a strong venture capital industry is harder still." ${ }^{\prime 65}$ Development of a private equity industry is a bit of a chicken and egg problem. On the one hand, venture capitalists are unlikely to supply funding to a firm without an established reputation; on the other, it is difficult for a firm to gain much of a reputation without funding. Regulation is necessary to bridge the gap between the venture capitalist seeking a profitable investment with limited risk, and the issuer seeking the private equity funding. Without at least limited regulation, the venture capitalist is likely to feel that he is taking on more risk than he is willing to bargain for - literally. In addition to the risk of the venture itself, he may be assuming the risks inherent in a weak regulatory system with limited property rights, disclosure and judicial enforcement and limited avenues for redress and exit. Indeed, private equity investments in small and hightech firms are more likely in countries with stronger guarantees against contract repudiation and shareholder rights. ${ }^{66}$ In countries where legal enforcement is poor, investors are likely to seek majority control of the firms they invest in to counteract their apparent inability to enforce contractual rights. ${ }^{67}$

In addition to limited regulation that will promote private equity investment by closing the gap between risk and potential reward, ensuring that there is an exit mechanism is a key element in creating a venture capital industry. Private equity investments typically do not pay dividends; rather, returns are derived from capital gains obtained upon exit. While a private sale to another company can be an

\footnotetext{
${ }^{63}$ For example, only ten percent of the voting shares would be necessary to call a shareholders meeting or to name a director.

${ }^{64}$ Financial Times, April 12, 2005

${ }^{65}$ Black 2000

${ }^{66}$ Cumming and Fleming 2003

${ }^{67}$ In contrast, private equity transactions in countries with greater contractual protections and better legal enforcement are more likely to be structured as convertible preferred stock than ordinary shares or debt. Lerner and Schoar 2004
} 
attractive and effective exit for equity investors, the more typical bait is the potential for an initial public offering (IPO). Private equity will not thrive in the absence of a "well-developed stock market that permits venture capitalists to exit through an initial public offering."68 Indeed, a venture capital industry and stock market development are positively correlated. “. . . IPOs are the strongest driver of venture capital investing, whereas GDP and market capitalization growth are not significant.”69 Thus, the establishment of the Neuer Markt in Germany, described above, also had a positive impact on the venture capital industry in Germany because it created a potential exit mechanism. ${ }^{70}$ The Mexican Sapi vehicle, described above, also seeks to bring together private equity with a potential exit mechanism.

In addition to serving as an exit opportunity, a stock exchange also promotes private equity because the infrastructure and the investment culture that tends to accompany an exchange are also important for private equity. For example, in bankcentered systems without a strong stock market, there is likely to be more of a conservative approach to lending and investing, the incentives that reward entrepreneurial behavior may be weaker and the penalties for failure stronger, and experienced private investors able to assess and contribute to a new venture may be limited. $^{71}$

The experience in Israel shows that the government can play an important role in promoting the emergence of a venture capital industry. In the early 1990's, in an attempt to capitalize on the skills of Russian immigrants arriving after the collapse of the Soviet Union, many of whom held academic degrees, the government of Israel allocated \$100 million to promote the new Yozma (Hebrew for 'initiative') program. Yozma was a fund of funds under which 10 venture capital funds were formed in partnership with leading foreign venture investors, who held a 60\% share. A major attraction of the Yozma program was the foreign investors' option to buy out the government's share at a pre-agreed price for a period of 5 years.

Ten venture capital funds were formed with a total of \$210 million under management, and 15 direct investments were made by Yozma itself. Nine out of the 15 direct investments enjoyed successful exits, either through IPOs or through acquisition, and nine of the ten foreign funds exercised their option and bought out the government's share. This helped lay the groundwork for an independent local venture capital industry comprising close to 80 venture capital funds, with total capital under management in excess of $\$ 10$ billion. $^{72}$

\footnotetext{
${ }^{68}$ Black and Gilson, 1997

69 Jeng and Wells 2000, cited in Claussens and Revilla 2005

${ }^{70}$ Burghof and Hunger, 2003

${ }^{71}$ Black and Gilson, 1997

${ }^{72}$ Israel Venture Association, http://www.iva.co.il/
} 


\section{Conclusion}

A simple legal and regulatory framework has many benefits that will help promote market development. Indeed, "stronger laws and regulatory institutions that protect investors (whether domestic or foreign) from colluding insiders are strongly correlated with deeper and more robust equity markets."73 A framework that emphasizes disclosure and enforcement, that facilitates listing for companies who are ready for a public commitment, that provides a legal mechanism for small companies to obtain financing outside the organized exchange, and that provides incentives for companies to develop good corporate governance practices including, most particularly, duties of care and loyalty to all shareholders, can begin to overcome the obstacles to development. This kind of simple regulatory framework, by facilitating entry and exit for companies and ensuring the protection of property rights for investors and issuers, is conducive to economic growth. Creating a positive business environment makes it more likely that all firms, both large and small, will be willing to participate in the market and therefore contribute to its overall growth. ${ }^{74}$

There is much evidence to indicate that these kinds of micro-structural improvements can have a positive impact on market development. In addition to creating opportunities for domestic market development, the quality of "housekeeping" and efficiency of "plumbing" in an emerging market have a positive influence on decisions by foreign portfolio investors to invest in the market. ${ }^{75}$ These kind of improvements also will further the potential for possible regionalization, which may be significant in many of the smaller markets.

Although the need to recognize the stage of a country's capital market development and the legal system that applies in the jurisdiction means that there is not one model of reform and the way in which reforms are implemented will vary depending on what works, it is possible to identify the basic necessities that need to be tackled to facilitate further development of the market in every developing country, regardless of its individual circumstances. These basic necessities apply to and will support all forms of primary market finance.

\section{Create a supportive environment.}

- Put fiscal practices on solid ground. Unstable macroeconomic conditions make it hard to predict behavior.

- Ensure that there are basic protections of property rights, and that data registries exist. These are the necessary foundations for disclosure and enforcement and to promote market confidence.

\footnotetext{
${ }^{73}$ P. Henry and P. Lorentzen, 2003, p. 181

${ }^{74}$ Demirguc-Kunt and Beck, February 2004. See, also, ““'Other things have to go with it [government to government assistance[, including . . . improving the climate for the private sector, and we don't just mean the climate for foreign direct investment, but even more importantly to improve the climate for the indigenous private sector, which has proven over and over again to be the engine for growth in successful developing economies. Interview with Paul Wolfowitz before the G-8 Summit in Gleneagles, Scotland, July 2005.

${ }^{75}$ Ladekarl and Zervos 2004
} 
- Encourage the growth of savings and invest in investor education and issuer training. These are necessary to build an equity culture.

2. Establish elements of basic market structure.

- Impose capital requirements on market intermediaries to provide a safety cushion that can reduce the risk of going to market for both issuers and investors.

- Ensure order handling and trading rules result in best execution of orders and transparency of dealings

- Clearance and settlement procedures for stock exchange transactions should at a minimum require settlement on the basis of delivery versus payment on the $3^{\text {rd }}$ day after orders have been executed

- Valuation mechanisms should address the deficiencies that arise when markets are illiquid

- Collective investment schemes can allow the pooling of savings of retail investors.

3. Impose fundamental disclosure requirements appropriate for the type of offering.

- Any company making an offer of shares should be required to disclose fully and fairly without omissions or misleading statements.

- High quality accounting and auditing standards must be imposed, and enforced.

- Impose more substantial disclosure requirements, such as continuous disclosure requirements, on those issuers making offerings on the formal exchange. Disclosure must be timely, and it should be reviewed and requirements enforced.

- Create a legal mechanism for a private offering that takes place off of the exchange and that will not be subject to review by the securities regulator. This can be a private placement or alternative form of financing. (This of course does not apply to exchange listings.)

4. Consider mandating specific corporate governance requirements.

- The accountability of the board of directors of the company to the entire company and its shareholders is key, and a range of different measures can be used to achieve this, depending on the market and the legal and regulatory context. For example, requirements for independent directors, for audit committees, lock-in provisions for majority shareholders, and providing voting rights to all shareholders are all specific measures that can be used to enhance the accountability of the board of directors.

5. Take enforcement seriously.

- These requirements should be able to be enforced either by the securities regulator or by an investor, or both. 
In addition to the basic legal and regulatory necessities identified above, there also needs to be a general awareness on the part of potential issuers and investors of the benefits of financial markets and a pool of skilled market intermediaries, policy makers, company directors, accountants, lawyers and financial analysts who have a deep understanding of the operations of the market to be able to contribute to capital market development. Education and training thus have an essential part to play in raising awareness in the community of the role of the capital market as a source of funding and investment and equipping market players with the skills they need for the market to operate effectively. With education and training, and the basic legal and regulatory infrastructure in place, a capital market will be better positioned to experience the growth and development necessary for it to serve as a source of financing for small-and-medium size companies and contribute to the health of the country's economy. 


\section{APPENDIX 1: Statistics for Selected Alternative Markets}

Source: FIBV, World Bank (for GDP figures)

Market Capitalization, \% of GDP

\begin{tabular}{|l|crrrrrrr|}
\hline Exchange & 1997 & 1998 & 1999 & 2000 & 2001 & 2002 & 2003 & 2004 \\
\hline Neuer Market (Germany) & NA & $2.2 \%$ & $3.5 \%$ & $4.3 \%$ & $2.4 \%$ & $0.5 \%$ & NA & NA \\
AIM (UK) & $0.7 \%$ & $0.5 \%$ & $1.5 \%$ & $1.6 \%$ & $1.2 \%$ & $1.1 \%$ & $1.8 \%$ & $2.8 \%$ \\
GEM (Hong Kong) & NA & NA & $0.6 \%$ & $5.2 \%$ & $4.8 \%$ & $4.2 \%$ & $5.8 \%$ & $5.3 \%$ \\
Kosdaq (S. Korea) & NA & NA & NA & $4.5 \%$ & $8.2 \%$ & $5.6 \%$ & $5.1 \%$ & $4.4 \%$ \\
\hline
\end{tabular}

\section{Market capitalization, USD Millions}

\begin{tabular}{|l|crrrrrrr|}
\hline Exchange & 1997 & 1998 & 1999 & 2000 & 2001 & 2002 & 2003 & 2004 \\
\hline Neuer Market (Germany) & NA & 46636 & 74571 & 80868 & 44460 & 10341 & NA & NA \\
AIM (UK) & 9304 & 7383 & 21705 & 22311 & 16893 & 16432 & 32865 & 60958 \\
GEM (Hong Kong) & NA & NA & 931 & 8627 & 7818 & 6695 & 9039 & 8583 \\
Kosdaq (S. Korea) & NA & NA & NA & 22937 & 39450 & 30848 & 31209 & 30048 \\
\hline
\end{tabular}

\section{New capital raised, USD Millions}

\begin{tabular}{|l|lllrrrrrr|}
\hline Exchange & \multicolumn{1}{|c}{1997} & 1998 & 1999 & 2000 & 2001 & 2002 & 2003 & 2004 \\
\hline Neuer Market (Germany) & NA & NA & 7090 & 11665 & 438 & 0 & NA & NA \\
AIM (UK) & N137 & \multicolumn{2}{c}{925} & 1506 & 4646 & 1626 & 1395 & 3435 & 8480 \\
GEM (Hong Kong) & NA & NA & NA & 2060 & 748 & 1166 & 596 & 678 \\
Kosdaq (S. Korea) & NA & NA & NA & 6402 & 2065 & 1079 & 2121 & 1632 \\
\hline
\end{tabular}

Capital raised, \% of market capitalization

\begin{tabular}{|l|ccrrrrrr|}
\hline Exchange & 1997 & 1998 & 1999 & 2000 & 2001 & 2002 & 2003 & 2004 \\
\hline Neuer Market (Germany) & NA & NA & $10 \%$ & $14 \%$ & $1 \%$ & $0 \%$ & NA & NA \\
AIM (UK) & $12 \%$ & $13 \%$ & $7 \%$ & $21 \%$ & $10 \%$ & $8 \%$ & $10 \%$ & $14 \%$ \\
GEM (Hong Kong) & NA & NA & NA & $24 \%$ & $10 \%$ & $17 \%$ & $7 \%$ & $8 \%$ \\
Kosdaq (S. Korea) & NA & NA & NA & $28 \%$ & $5 \%$ & $3 \%$ & $7 \%$ & $5 \%$ \\
\hline
\end{tabular}

\section{Number of companies with shares traded}

\begin{tabular}{|l|clrrrrrrr|}
\hline Exchange & \multicolumn{1}{|c}{1997} & 1998 & 1999 & 2000 & 2001 & 2002 & 2003 & 2004 \\
\hline Neuer Market (Germany) & NA & NA & 201 & 339 & 326 & 240 & NA & NA \\
AIM (UK) & 308 & & 312 & 347 & 524 & 629 & 704 & 754 & 1021 \\
GEM (Hong Kong) & NA & NA & & 7 & 54 & 111 & 166 & 185 & 204 \\
Kosdaq (S. Korea) & NA & NA & NA & & 540 & 702 & 830 & 874 & 887 \\
\hline
\end{tabular}




\section{Turnover ratio*}

\begin{tabular}{|l|ccrrrrrr|}
\hline Exchange & \multicolumn{1}{|c}{1997} & 1998 & 1999 & 2000 & 2001 & 2002 & 2003 & 2004 \\
\hline Neuer Market (Germany) & NA & NA & $184 \%$ & $379 \%$ & $198 \%$ & $326 \%$ & NA & NA \\
AIM (UK) & $21 \%$ & $22 \%$ & $20 \%$ & $46 \%$ & $21 \%$ & $16 \%$ & $17 \%$ & $27 \%$ \\
GEM (Hong Kong) & NA & NA & NA & $125 \%$ & $65 \%$ & $84 \%$ & $54 \%$ & $39 \%$ \\
Kosdaq (S. Korea) & NA & NA & NA & $1994 \%$ & $821 \%$ & $796 \%$ & $716 \%$ & $501 \%$ \\
\hline
\end{tabular}

*Annual trading value/end-year market capitalization

Value of share trading, USD Millions

\begin{tabular}{|c|c|c|c|c|c|c|c|c|}
\hline Exchange & 1997 & 1998 & 1999 & 2000 & 2001 & 2002 & 2003 & 2004 \\
\hline $\begin{array}{l}\text { Neuer Market } \\
\text { (Germany) }\end{array}$ & NA & NA & 136970 & 306732 & 88082 & 33681 & NA & NA \\
\hline AIM (UK) & 1977 & 1604 & 4356 & 10282 & 3500 & 2648 & 5434 & 16636 \\
\hline GEM (Hong Kong) & NA & NA & NA & 10815 & 5053 & 5638 & 4901 & 3307 \\
\hline Kosdaq (S. Korea) & NA & NA & NA & 457304 & 323699 & 245701 & 223569 & 150402 \\
\hline
\end{tabular}




\section{References}

Anderson, R., and D. Reeb, 2004 The Balance of Power: Who Monitors the Family?”

Beck, T., and A. Demirguc-Kunt, 2004. SMEs, Growth, and Poverty: Do Pro-SME Policies Work? World Bank Viewpoint Note No 268.

Berglof, E., and S. Claessens, 2004. Corporate Governance and Enforcement, World Bank Policy Research Working Paper 3409.

Berkowitz, D., K. Pistor, and J-F. Richard, 1999. Economic Development, Legality, and the Transplant Effect.

Black, B.S., 2001. The Legal and Institutional Preconditions for Strong Securities Markets, 48 UCLA Law Review 781.

Black, B.S., and R.J.Gilson, 1997. Venture capital and the structure of capital markets: Banks versus stock markets.

Blommestein, H.J., 2003. Major Policy Challenges in Developing Exchanges in Emerging Economies, Financial Market Trends; Oct 2003, 85, ABI/INFORM Global 123.

Burghof, H-P., and A. Hunger, 2003. Access to Stock Markets for Small and Medium Sized Growth Firms: The Temporary Success and Ultimate Failure of Germany's Neuer Markt.

Bushee, B.J., and C. Leuz, 2005. Economic consequences of SEC disclosure regulation: Evidence from the OTC bulletin board, Forthcoming Journal of Accounting and Economics 39 (2).

Cameron, A., 2003. Supervision at the Micro Level: Do Disclosure-Based Regimes Work? Paper given at World Bank, IMF, and Brookings Institution conference The Future of Domestic Capital Markets in Developing Countries, Washington, April 2003.

Chemmanur, T.J., and P. Fulghieri, 2003. Competition and Co-operation among Exchanges: A Theory of Cross Listing and Endogenous Listing Standards.

Claessens, S., D. Klingebiel and S. Schmukler, 2004. Accessing International Equity Markets: What firms from Which Countries Go Abroad? Background paper to A. de la Torre and S. Schmukler, 2004.

Coffee, Jr. J.C., 1999. Privatisation and Corporate Governance: The Lessons from Securities Market Failure, Columbia Law School Working Paper No 158. 
Coffee, Jr. J.C., 2002. Competition among Securities Markets: A Path Dependent Perspective, Columbia Law School Working Paper No 192.

Coffee, Jr. J.C., 2002. Racing towards the top?: The Impact of Cross-Listings and Stock Market Competition on International Corporate Governance, Columbia Law School Working Paper No 205.

Cohn, S., 2004. A New Direction for African Capital Markets: Facilitating Capitalraising Opportunities for Small and Medium-sized Enterprises, United Nations Institute for Training and Research (UNITAR) Document No 20.

Cumming, D., and G. Fleming, 2003. A Law and Finance Analysis of Venture Capital Exits in Emerging Markets, Australian National University, Technical Report Working Series.

De la Torre, A. and S.Schmukler, 2004. Whither Latin American Capital Markets? World Bank.

Dewenter, K.L., C-S. Kim, U. Lim, and W.Novaes, 2005. Committing to protect investors in emerging markets: Can local exchanges provide value-relevant bonding mechanisms? Available at SSRN, www.ssrn.com.

Doidge, C., G.A. Karolyi, and R.M. Stulz, 2004. Why do countries matter so much for corporate governance? European Corporate Governance Institute, Finance Working Paper No 50,

Frost, C.A., E.A. Gordon and A.F. Hayes, 2002. Stock Exchange Disclosure and Market Liquidity: An Analysis of 50 International Exchanges. Available at SSRN, www.ssrn.com.

Greenspan, A., 2000. Remarks at the Council on Foreign Relations.

Hargis, K., 2000. International cross-listing and stock market development in emerging economies, International Review of Economics and Finance 9 (2000) 101-122.

Henry, P.B., and P.L. Lorentzen, 2003. Domestic Capital Market Reform and Access to Global Finance: Making Markets Work, National Bureau of Economic Research, NBER Working Paper 10064.

International Organization of Securities Commissions, 2003. Objectives and Principles of Securities Regulation.

Jordan, C., and M. Lubrano, 2002. How Effective are Capital Markets in Exerting Governance on Corporations? in Financial Sector Governance: The Roles of the Public and Private Sectors, R.E.Litan, M. Pomerleano and V Sundarajan eds. Washington D.C. Brookings Press. 
Kim, Y., forthcoming, The Links between Privatisation and Stock Market Development in the People's Republic of China, World Bank.

Klapper, L., and I.Love, 2002. Corporate Governance, Investor Protection, and Performance in Emerging Markets, World Bank Policy Research Working Paper 2818.

Ladekarl, J., and S. Zervos, 2004. Housekeeping and Plumbing: The Investability of Emerging Markets, World Bank Policy Research Working Paper 3229.

La Porta, R., F. Lopez-de-Silanes, and A. Shliefer, 2003. What Works in Securities Laws? NBER Working Paper No 9882.

Latin American Shadow Financial Regulatory Committee, 2005. Putting Pension Funds to Work in Latin America: New Financial Instruments to help Deepen Financial Markets, Statement No. 13.

Leuz, C., A.Triantis, and T. Wang, 2004. Why do Firms Go Dark? Causes and Consequences of Voluntary SEC Deregistrations. Wharton School, University of Pennsylvania.

Lopez-de-Silanes, F., 2004. A Survey of Securities Laws and Enforcement, World Bank Policy Research Working Paper 3405.

Lopez-de-Silanes, F., 2000. Reforming and Deepening Mexico’s Financial Markets, Council of Foreign Relations Working Group on Development, Trade, and International Finance.

Macey, J., M. O’Hara, and D.Pompilio, 2004. Down and Out in the Stock Market: The Law and Finance of the Delisting Process.

Mann, M.D., 1993. What Constitutes a successful Securities Regulatory Regime? Australian Journal of Corporate Law, Vol 3 No 2.

Marchisio, G., and D. Ravasi, 2001. Family firms and the decision to go public: A study of Italian IPOs. SDA BOCCONI, Research Division Working Paper No. 01-45.

McMillan, J., and C. Woodruff, 2002. The Central Role of Entrepreneurs in Transition Economies, Journal of Economic Perspectives, Volume 16, Number 3, 153-170.

Nenova, T., 2004. A Corporate Governance Agenda for Developing Countries, World Bank.

Ritter, J., 2005. Introduction to Recent Developments in Corporate Finance, Edward Elgar Publishing.

Sylla, R., 1995. The Rise of Securities Markets: What can Government Do? World Bank Policy Research Working Paper 1539. 
Wang, S-D., 2003. The development of e-financing: implications for SMEs, Bulletin on Asia-Pacific Perspectives 2003/04 77-84.

Welch, I., and J. Ritter, 2002, A Review of IPO Activity, Pricing and Allocations, Yale ICF Working Paper, No. 02-01.

Zervos, S., 2004. The Transactions Costs of Primary Market Issuance: The Case of Brazil, Chile, and Mexico, World Bank Policy Research Paper 3424. 